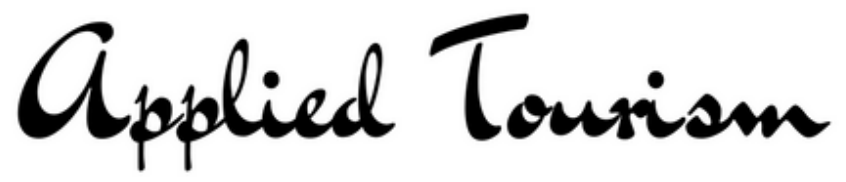 (2)

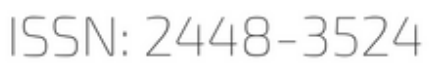 \\ v.1 - n2 - $2016-97-114$ \\ UNIVNLI
}

\section{A COZINHA DE FUSÃO ENCONTRA O RIO: PEIXES NATIVOS AMAZÔNICOS COMO ALTERNATIVA PARA A CULINÁRIA JAPONESA}

\section{FUSION CUISINE MEETS THE RIVER: NATIVE AMAZONIAN FISH AS AN ALTERNATIVE FOR JAPANESE FOOD}

\author{
Hellen Christina de Almeida Kato - Mestre em Ciência e Tecnologia dos Alimentos \\ Universidade Federal do Pará (UFPA). E-mail: hellen.almeida@embrapa.br \\ LUANA DE SOUSA OLIVEIRA - Mestre em Turismo e Hotelaria \\ Universidade do Vale do Itajaí (Univali).E-mail: luana@ifto.edu.br \\ Érrika da Silva Maciel - Doutora em Qualidade de Alimentos \\ Universidade de São Paulo (USP).E-mail: erikasmaciel@gmail.com \\ Alexandre Aires de Freitas - Mestre em Agronomia \\ Universidade Federal do Ceará (UFC).E-mail: alexandre.freitas@embrapa.br
}

Recebido/Received: 16 junho/june 2015. Aprovação/Approval: 06 maio/may 2016

DOI: $10.14210 /$ at.v1n2.p97-114

\begin{abstract}
RESUMO: A culinária japonesa, desde a década de 80 , se expande no Brasil, conservando técnicas e ingredientes de sua origem combinadas a inovações relacionadas à culinária americana, sendo assim, bastante dependente de ingredientes importados. Através da cozinha de fusão, esse trabalho sugere o uso de espécies de peixes nativos cultivados na Amazônia como alternativa gastronômica para esse mercado. Foi realizado um experimento envolvendo chefs de cozinha amazônica e japonesa desenvolvendo seis preparações a base de pirarucu e tambaqui. Estas foram avaliadas por um painel
\end{abstract}

ABSTRACT: Since the 1980s, Japanese food has gained ground in Brazil while preserving its original techniques and ingredients combined with innovations from the American cuisine, hence it greatly depends on imported ingredients. Through fusion cuisine, the present study suggests the use of native fish species farmed in the Amazon as a food alternative for this market. An experiment was carried out involving Amazon and Japanese cuisine chefs who prepared six dishes based on pirarucu and tambaqui. These dishes were evaluated by a panel with 24 experienced aquiculture professionals and Japanese 
treinado de 24 profissionais da aqüicultura e gastronomia japonesa. Avaliou-se a aceitação e seus atributos utilizando uma escala hedônica com aplicação de questionário estruturado de intenção de compra. Todos os pratos obtiveram ampla aceitação, tendo destaque o Teppan de pirarucu. Conclui-se que o uso dos peixes nativos de cultivo da Amazônia, tambaqui e pirarucu, é uma alternativa viável para a inovação da gastronomia japonesa no Brasil, através da culinária de fusão.

Palavras-chave: Amazônia; Cozinha fusion; Peixes de água doce.

\section{INTRODUÇÃO}

Desde que desembarcou no Brasil com os primeiros imigrantes, em 1908, a bordo do navio Kasato Maru, a culinária japonesa percorreu um caminho, análogo às tendências que ocorriam no mundo inteiro e foi ganhando espaço e se popularizando entre os brasileiros. Hoje, pratos que se utilizam de técnicas da cozinha japonesa são servidos nas maiorias das cidades em todo o território brasileiro.

Essa cozinha, que tem no peixe a sua proteína animal principal, faz parte do cotidiano de grandes e pequenas cidades, no entanto, é dependente em sua maioria de ingredientes importados que aumentam o custo dos preparos elevando cada vez mais o ticket médio de seu consumo.

O objetivo deste trabalho é através da cozinha de fusão, propor novos caminhos para a culinária japonesa do Brasil, através do uso de espécies nativas amazônicas, que em conjunto às técnicas e o leque de sabores desta cozinha, podem tornar-se um novo nicho de mercado para a produção de peixes nativos e um poderoso atrativo quando se fala em turismo gastronômico.

\section{A CULINÁRIA JAPONESA}

A cozinha japonesa é diferenciada em seu preparo, seus sabores e sua apresentação, devido a inúmeros fatores históricos e culturais, constituiu-se uma culinária cheia de ritos e tradição, fortemente marcada pela sua característica saudável e apoiada em uma tríade: Arroz, verduras e a proteína animal, fundamentalmente, peixes.

O arroz é o centro da alimentação japonesa desde seus primórdios. Uma sociedade fundamentalmente agrícola, que cuisine experts. The acceptability of dishes and attributes were assessed using a hedonic scale through a structured questionnaire examining the purchase intention. All dishes were widely accepted, especially pirarucu teppan. It is concluded that the use of the farmed native Amazon fish tambaqui and pirarucu is a viable alternative to innovate the Japanese gastronomy in Brazil through fusion cuisine.

Keywords: Amazon, fusion cuisine, freshwater fish

\section{INTRODUCTION}

Since it reached Brazil along with the first immigrants in 1908 onboard the ship Kasato Maru, Japanese cuisine has gone a long way, analogous to the worldwide trends, and have gained ground and popularity among Brazilians. Today, dishes using Japanese cuisine techniques are served in most cities all over the country.

This cuisine, whose main animal protein is fish, is part of the daily life in large and small cities, however, it mostly depends on imported ingredients, which adds costs and raises the average ticket for its consumption.

This study aims to use fusion cuisine to propose new ways for Japanese gastronomy in Brazil by using native Amazonian fish species, which, in conjunction with the techniques and array of flavors of that cuisine, may become a new market niche for the production of native fish species and a powerful appeal when it comes to food tourism.

\section{JAPANESE CUISINE}

Japanese cuisine stands apart for its preparation, flavors and presentation due to countless historic and cultural factors. Filled with ritual and tradition, it is strongly marked by a healthy character, based on a triad: rice, vegetables, and animal protein, particularly fish.

Rice has been the core of Japanese diet since ancient times. It was fundamentally an agricultural society which, during the Middle Ages, actually used food as currency to pay levies. Rice, or gohan, is the basis of the meal and is complemented by leafy greens and vegetables cut in small shapes and prepared cooked or pickled. The side dishes, or okazu, include greens and fish flavored mainly with 
durante a Idade Média, chegou a usar o alimento como moeda para o pagamento de impostos. O arroz ou gohan é a base da refeição, complementada por verduras e legumes talhados em pequenos formatos e preparados em cozidos ou conservas. Estes acompanhamentos ou okazu, verduras e peixes temperados, principalmente, com shoyu ou misso. O molho (shoyu) e a pasta de soja (misso) dão um sabor característico à cozinha de todo o país (Ribeiro \& Paolucci, 2006; Silva, Soares \& Wolf, 2011).

A proteína animal principal é o pescado. Isso porque, durante os séculos VI e VII, o budismo, religião predominante no Japão naquele momento, proibiu a matança de animais, fazendo com que seus seguidores baseassem sua dieta em cardápios ricos em vegetais, complementados com peixes como fonte principal de proteína animal, daí a fundamental importância deste ingrediente na cozinha japonesa, costume que se estendeu aos dias atuais devido à geografia do país que favorece a obtenção de peixes, crustáceos e mariscos (Carneiro, 2003).

A esta tríade incorporam-se outros ingredientes também bastante marcantes desta culinária como o nori (algas comestíveis da espécie Porphyra, em finas folhas secas), frutas, hortaliças e o massas feitas a partir de peixe como o kani e o kamaboko. Temperos e especiarias comuns são o karashi (tipo de mostarda japonesa), a raiz forte (wasabi) e o gengibre (Medina, 2006).

\section{IMIGRAÇÃO E A CULINÁRIA JAPONESA NO BRASIL}

O início da imigração japonesa em 1908 representou o início do contato significativo da sociedade brasileira com a cultura japonesa como um todo. Estima-se que, entre 1908 e 1940, cerca de 190 mil japoneses imigraram para o Brasil, quase todos contando com alguma espécie de subsídio. Com o início da2a Guerra Mundial, o Japão foi declarado país inimigo. Neste tempo, ganhou força discurso de repúdio à cultura japonesa - o "perigo amarelo". Depois da guerra, contudo, principalmente a partir da década de 1960 , o Japão se torna gradativamente um símbolo de modernidade, desenvolvimento e progresso, um modelo no caminho brasileiro (Martins, 1997; Oda, 2011).

Chegando ao Brasil, uma das maiores dificuldades dos imigrantes foi a cozinha. shoyu or misso. The soy sauce (shoyu) and paste (misso) confer a characteristic flavor to the country's cuisine (Ribeiro \& Paolucci, 2006; Silva, Soares \& Wolf, 2011).

The main animal protein is fish. This derives from the fact that, during the 6th and 7th centuries, Buddhism - then the prevailing religion in Japan - prohibited animal slaughter, which made its followers turn to a diet rich in vegetables and complemented with fish as the main source of animal protein. This habit persevered until current days due to the country's geography that favors the obtention of fish, crustaceans, and shellfish (Carneiro, 2003).

This triad is joined by other ingredients that are also peculiar to this culinary such as nori (edible Porphyra algae in thin dry sheets), fruits, vegetables, and fish-based pastes such as kani and kamaboko. Common seasonings and spices are karashi (a type of Japanese mustard), wasabi, and ginger (Medina, 2006).

\section{IMMIGRATION AND JAPANESE CUISINE IN BRAZIL}

The start of Japanese immigration in 1908 represented the beginning of a significant contact of the Brazilian society with Japanese culture as a whole. It is estimated that, between 1908 and 1940, about 190 thousand Japanese immigrated to Brazil, nearly all with some kind of subsidy. With the start of the Second World War, Japan was declared an enemy country. During this time, the discourse abhorring Japanese culture took hold - the "yellow danger." After the war, however, mainly from the 1960s onwards, Japan gradually became a symbol of modernity, development, and progress, a model in the Brazilian path (Martins, 1997; Oda, 2011).

At their arrival in Brazil, one of the greatest hurdles for immigrants was the cuisine. They had trouble preparing the Brazilian long-grain rice, whose texture was not similar to the Japanese variety. On farms, the jerked beef and the cod, due to their strong odor and taste, were unpleasant to the Japanese palate. Of the Brazilian cuisine, only beans were easily adopted, although it was cooked with sugar (Handa, 1987). The author also reports on the dietary habits of this population in Brazil

Even after spending about ten years in Brazil, the first immigrants had not been able to learn how to season the food. After so much 
Havia dificuldade em preparar o arroz brasileiro (agulha) que não se assemelhava em textura ao japonês. Nas fazendas as carnes secas disponíveis e o bacalhau que devido ao cheiro e sabor forte não agradavam o paladar japonês. Da culinária brasileira, apenas o feijão foi adotado com facilidade, no entanto, cozido com açúcar (Handa, 1987). A autora conta ainda sobre os costumes alimentares desta população no Brasil

\begin{abstract}
Mesmo depois de passar cerca de dez anos no Brasil os primeiros imigrantes não haviam conseguido aprender o modo de temperar a comida. Depois de tanto tempo já se fazia misso nas fazendas. 0 shoyu era vendido apenas nas cidades, o que significava que só começou a aparecer quando os japoneses, com o aumento de sua população, começaram a procurar as cidades para as suas moradias. Nos primeiros tempos, utilizava-se como substituto do Shôyo o caldo que sobrava no barril de misso. Só depois de 1915, com o aparecimento de jornais, é que iriam saber de sua existência. Um prato sem tempero ou sem shoyu, mas feito com ingredientes brasileiros, era algo realmente esquisito.
\end{abstract}

A partir de 1914 já se registram restaurantes e hotéis servindo comida japonesa no estado de São Paulo. O número cresce especialmente, na capital e no interior na década de 20, com destaque para os rizoriya, restaurantes mesclados a pontos de diversão masculina, onde os imigrantes amenizavam a saudade da terra natal. Em 1935, já se registrava uma infinidade de restaurantes, doceiras, fábricas de misso, shoyu e tofu funcionando em solo brasileiro, no entanto, esses locais não eram frequentados por brasileiros, que apresentaram uma resistência inicial aos pratos da culinária japonesa (Handa, 1987; Holzmann, 2006).

Essas casas permaneceram lugares frequentados por saudosos imigrantes e seus descendentes até meados da década de 80 , quando a culinária japonesa passou por seu ponto de virada, começando a ser apreciada, consumida e incorporada ao cardápio de brasileiros com certa naturalidade (Collaço, 2009).

Além disso, a cultura japonesa é de interesse crescente entre os jovens brasileiros, um aspecto interessante é a associação que estes jovens e a população de um modo geral passaram a manter entre a comida japonesa e uma alimentação saudável, que auxilia no time, misso was being made in the farms. Shoyu was sold only in the cities, which meant it only came around when the Japanese, as their population increased, began seeking housing in the cities. In the early times, they replaced shoyu with the leftover slurry in misso barrels. Only after 1915, as the newspapers appeared, would they learn about its existence. A dish with no seasoning or shoyu, but made with Brazilian ingredients, was something truly odd.

As early as 1914, there were records of restaurants and hotels serving Japanese in the state of São Paulo. The number grew, both in and out of the state capital, in the 1920s, in special the rizoriya, part restaurants, part male entertainment houses, where the immigrants remembered their homeland. In 1935, there were countless restaurants, confectioneries, and misso, shoyu, and tofu factories on Brazilian soil. However, such places were not attended by Brazilians, who had an early distate for the Japanese dishes (Handa, 1987; Holzmann, 2006).

These establishments remained gathering points of homesick immigrants and their descendants until the middle 1980s, when Japanese cuisine had its turning point and began being appreciated, consumed, and naturally incorporated into the diet of Brazilians (Collaço, 2009).

Moreover, the interest in Japanese culture is ever growing among the Brazilian youth. An interesting aspect is the association these youngsters, and the overall population, made between Japanese food and a healthy diet that aids in weight control (Reichembarch, 2007). Japanese dishes gained popularity in the wake of the spread of the Eastern modus vivendi (Ribeiro, 2005). In 2003, the number of Japanese restaurants surpassed the number of steakhouses in São Paulo (Minami, 2015).

\section{CULTURAL HERITAGE AND FUSION CUISINE}

The gastronomy is part of a people's cultural heritage, since, as stated by Brayner (2007), "the cultural heritage of a people is formed by the collection of the knowledge, actions, expressions, practices and their products that recall this people's history, memory, and identity." Through the cuisine, a population passes on its know-how, tradition, and memories expressed through the senses: 
controle do peso (Reichembarch, 2007). Pratos japoneses tornaram-se populares, acompanhando uma disseminação do modus vivendi oriental (RIBEIRO, 2005). Em 2003, o número de restaurantes de culinária japonesa ultrapassou o número de churrascarias em São Paulo (Minami, 2015).

\section{PATRIMÔNIO CULTURAL E A COZINHA DE FUSÃO}

A gastronomia é um dos constituintes do patrimônio cultural de um povo, já que como afirmado por Brayner (2007) "patrimônio cultural de um povo é formado pelo conjunto dos saberes, fazeres, expressões, práticas e seus produtos, que remetem à história, à memória e à identidade desse povo". Através da gastronomia, uma população transmite seu saber fazer, tradições e memórias expressas através dos sentidos: odor, visão, o sabor e até a audição. (Barroco \& Barroco, 2008). Ainda sobre a relação entre a alimentação e o patrimônio cultural Sonati, Vilarta e Silva (2009) defendem que

$$
\begin{aligned}
& \text { A identidade de um povo se dá, } \\
& \text { principalmente, por sua língua e por } \\
& \text { sua cultura alimentar. Um conjunto } \\
& \text { de práticas alimentares determinadas } \\
& \text { ao longo do tempo por uma sociedade } \\
& \text { passa a identificá-la e muitas vezes, } \\
& \text { quando enraíza, se torna patrimônio } \\
& \text { cultural. }
\end{aligned}
$$

Assim, a gastronomia local é o reflexo e a valorização da própria população que conhece e prepara os seus alimentos de modo diferenciado e peculiar. Essa cozinha tradicional representa os hábitos alimentares em sua essência - mantendo produtos típicos, modos de preparo e costumes à mesa mesmo que esta população esteja afastada de sua região de origem (Cunha \& Oliveira, 2009). Schlüter (2003), diz que

\begin{abstract}
A identidade também é expressa pelas pessoas através da gastronomia, que reflete suas preferências e aversões, identificações e discriminações, e, quando imigram, a levam consigo, reforçando seu sentido de pertencimento ao lugar de origem. Dessa forma vai-se criando uma cozinha de caráter étnico, explorada com muita frequência no turismo para ressaltar as características de uma cultura em particular.
\end{abstract}

Como fruto de imigrações é inegável que o contato entre culturas resulta em influência smell, sight, taste, and even hearing (Barroco \& Barroco, 2008). Regarding the relation between diet and cultural heritage, Sonati, Vilarta, and Silva (2010) argue that

The identity of a people is expressed,
mainly, through its language and its
dietary culture. A set of dietary practices
determined over time by a society comes
to identify it and often, when it lays
roots, it becomes a cultural heritage.

Thus, the local gastronomy is the reflection and valuing of the very population that knows and prepares its food in a unique and peculiar way. This traditional cuisine represents the dietary habits in their essence - maintaining typical products, forms of preparation, and habits at the table - even if this population is away from its land (Cunha \& Oliveira, 2009). Schlüter (2003) states that

\begin{abstract}
Identity is also expressed by the people through gastronomy, which reflects its preferences and aversions, identifications and discriminations, and, when they immigrate, they take it along, strengthening their sense of belonging to the homeland. Thus, an ethnic cuisine is created, which is often explored in tourism to highlight the characteristics of a particular culture.
\end{abstract}

As a result of immigration, it is undeniable that the contact between cultures results in mutual influence, which has been termed hybridism, and that also occurs in gastronomy - the fusion between different cultures as a powerful creative source (Figueiredo, 2009). Fusion cuisine spawns in this context, suggesting new techniques, ingredients, and versions to prepare the traditional dishes of a population, aggregating adaptations from one place to the other, but maintaining the colors, flavors, spices, history, and culture.

Zaneti (2012) defines this cuisine as "fusing together regional foods with international techniques; revisiting traditional dishes with regional foods; and using regional and global elements in the same dish." The author narrates that, since the 1970s, a large flow of international chefs to Brazil began, they brought in their luggage the value of using fresh, regional products while respecting the local culture and product seasonality. This movement gained traction in the 1980s, strengthening the use of Brazilian products in its recipes, techniques, and restaurants.

The Eastern and Western cuisines began exchanging spices, fruits, vegetables, meats, 
mútua, o que tem sido chamado de hibridismo, o que ocorre também na gastronomia a fusão entre diferentes culturas como poderosa fonte criativa (Figueiredo, 2009). Nesse contexto, encontra-se a cozinha de fusão sugerindo novas técnicas, ingredientes e versões para preparos tradicionais de uma população, agregando adaptações de um lugar para o outro, mas mantendo cores, sabores, temperos história e culturas.

Zaneti (2012) define essa cozinha como "fusionar alimentos regionais com técnicas internacionais; fazer releituras de preparos tradicionais com alimentos regionais; e utilizar elementos regionais e mundiais em um mesmo preparo". A autora narra que partir dos anos 70, se iniciou um grande fluxo de chefs internacionais para o Brasil, trazendo em sua bagagem a valorização do uso de produtos frescos, regionais, respeitando a cultura local e a sazonalidade dos produtos. Esse movimento ganhou força na década de 80 , reforçando o uso dos produtos brasileiros em suas receitas, técnicas e restaurantes.

A gastronomia do oriente e do ocidente passam a trocar temperos, frutas, hortaliças, carnes, castanhas, técnicas, culturas, costumes e hábitos deixando os sabores do mundo sem fronteiras, dando início à globalização (Zaneti, 2012).

Para Collaço (2009) a cozinha de fusão é ainda definida como a cozinha resultante da construção feita pelo que se traz de outro país com a influência do país que recebe. Este processo cria uma integração e um intercâmbio de comidas e valores que refletem a não só a geografia, mas também a cultura de seu povo (Fajans, 2013).

Sampaio (2010) cita a cozinha de fusão como uma das ferramentas da culinária moderna para a promoção do turismo gastronômico, por refletirem transformações e interculturalidades peculiares de um local. Isso porque, recortes ou acontecimentos históricos têm resultados especiais na história da gastronomia, pois, a partir deles, os sabores do mundo se miscigenam.

\section{O ORIENTE ENCONTRA AS COZINHAS OCIDENTAIS}

Apesar do surgimento de restaurantes japoneses no Brasil ainda no início do século $\mathrm{XX}$, devido às características imigratórias, em outros países do ocidente, como Europa e Estados Unidos, esse surgimento ocorreu nuts, techniques, cultures, customs, and habits, leading the way to a borderless, globalized world (Zaneti, 2012).

To Collaço (2009), fusion cuisine is also defined as the cuisine resulting from the construction based on what is brought from abroad with the influence of the receiving country. This process leads to an integration and exchange of foods and values that reflect not only the geography, but also the culture of its people (Fajans, 2013).

Sampaio (2010) mentions fusion cuisine as one of the tools of modern cookery to promote food tourism since it reflects the transformations and interculturality particular of a certain place. That occurs because snippets or historic events have special results on the history of gastronomy since, from them, the flavors of the world miscegenate.

\section{THE EAST MEETS THE WESTERN CUISINES}

Despite the rise of Japanese restaurants in Brazil already in the early 20th century, due to the characteristics of immigration, in other Western countries, such as European countries and the United States, this phenomenon took place only in the 1960s (Cwiertka, 2005; Laemmerhirt, 2010). In American restaurants, to make the Japanese dishes more attractive to patrons, techniques of this cuisine were employed while aggregating fresh, seasonal ingredients such as avocado (Laemmerhirt, 2010).

This newborn fusion became part of the so-called Californian cuisine and received influence not only of Japanese techniques, but also combining the Mediterranean cuisine. Nowadays, the dishes created in this first contact have reached several countries, including Japan itself, where they are seen not as versions of the traditional Japanese food, but as new dishes created by Americans. Laemmerhirt (2010) states

In most cases, the unknown food is not consumed and accepted in its original state but is modified in order to please the local palate; modern eating today is more often than not "compromised, globalized, and creolized." Dishes are modified according to the availability of ingredients or their tastes, and, therefore, the majority of dishes in cookbooks and restaurants with a supposedly foreign origin are "rather 
apenas na década de 60 (Cwiertka, 2005; Laemmerhirt, 2010). Em restaurantes americanos, para tornar pratos japoneses mais atrativos para clientes, empregouse as técnicas desta cozinha agregando ingredientes frescos, da estação como o abacate (Laemmerhirt, 2010).

Esta fusão recém-nascida passou a fazer parte da chamada cozinha californiana, recebendo influências não só das técnicas japonesas, mas também, realizando combinações com a cozinha mediterrânea. Hoje, as preparações criadas neste primeiro contato chegaram a diversos países, incluindo o próprio Japão, onde são vistos não como versões da comida tradicional japonesa, mas, um novo prato criado por americanos. Laemmerhirt (2010) afirma

\begin{abstract}
In most cases, the unknown food is not consumed and accepted in its original state but is modified in order to please the local palate; modern eating today is more often than not "compromised, globalized, and creolized." Dishes are modified according to the availability of ingredients or their tastes, and, therefore, the majority of dishes in cookbooks and restaurants with a supposedly foreign origin are "rather products of the imagination of their creators".
\end{abstract}

Historicamente, portanto, o século XX representou o período em que a cozinha japonesa acumulou influências do ocidente e se adaptou às necessidades da sociedade moderna. Ingredientes como shoyu (molho de soja), wasabi (raiz forte), misso (pasta de soja), karashi (mostarda), mirin e sake (bebidas alcoólicas à base de arroz) e dashi (caldo de peixe ou carne) passaram a fazer parte do cotidiano de milhões de pessoas em todo o mundo (Cwiertka, 2005).

No Brasil, receitas tradicionais e produtos de fusão são itens bastante apreciados em restaurantes de culinária japonesa. Os resultados da experiência americana são conhecidos como Sushi Califórnia, uma combinação de salmão ou kani a ingredientes tropicais como manga, abacate e morango, e os Hot sushis (como o Filadélfia) - sushis preparados em massas de empanar e farinha de pão (panko), servidos fritos.

\section{O MERCADO DE PESCADOS NO BRASIL E OS PEIXES AMAZÔNICOS}

O Brasil, mesmo estando entre os 20 maiores produtores mundiais de pescados, products of the imagination of their creators".

Historically, thus, the 20th century represented the period in which Japanese cuisine accumulated Western influences and adapted to the needs of the modern society. Ingredients such as shoyu, wasabi, misso, karashi, mirin and sake (rice-based alcoholic beverages), and dashi (fish or meat stock) have become part of the daily life of millions of people around the world (Cwiertka, 2005).

In Brazil, traditional recipes and fusion products are widely appreciated in Japanese restaurants. The results of the American experience are known as California sushi, a combination of salmon or kani and tropical ingredients such as mango, avocado, and strawberry, and hot sushi (such as Philadelphia) - sushi prepared in breading mix and bread flour (panko) served fried.

\section{THE FISH MARKET IN BRAZIL AND THE AMAZONIAN FISH SPECIES}

Although Brazil is among the top 20 fish producers worldwide, it is a major importer of fish to meet the growing internal demand, particularly of species that cannot be captured in Brazilian waters. Among the imported species, salmon - widely used in Japanese cuisine - holds first place (Boletim estatístico da pesca e aquicultura [Fishery and Aquaculture Statistics], 2011).

In 2013, salmon imports corresponded to USD 467 million, or $36.6 \%$ of the total Brazilian fish imports, and its price by the ton varied by 47\% between 2013 and 2014 (Torre, 2014). This scenario is worrisome, particularly in view of the current loss of value of the Brazilian currency in face of the American dollar.

Therefore, the cost of raw materials in Japanese restaurants has been rising. Since it is the type of enterprise with the highest average price among the food business (Minami, 2015), viable alternatives that are well accepted by the customers must be sought.

The Amazon presents as a new source of inspiration and ingredients for chefs of all types of cuisines. Ingredients such as tucupi, jambu, chili pepper, Brazil nut, and the Amazonian fish species have been present in the ( $r$ )evolution of the Brazilian cuisine led by chefs such as Alex Atala, Claude Troigrois, and Ana Trajano (Fajans, 2013). The author describes 
é um grande importador de peixe para responder à crescente demanda do mercado interno, sobretudo de peixes que não podem ser pescados em águas brasileiras. Dentro das espécies importadas, o salmão, peixe muito utilizado na culinária japonesa, ocupa o primeiro lugar (Boletim estatístico da pesca e aquicultura, 2011).

Em 2013, a importação de salmão correspondeu a US $\$ 467$ milhões ou $36,6 \%$ da receita total de importações brasileiras, sendo que o preço da tonelada chegou a variar $47 \%$ entre 2013 e 2014 (Torre, 2014). Este cenário é preocupante, principalmente tendo-se em vista as atuais desvalorizações da moeda brasileira em relação à moeda americana.

Desse modo, o custo de obtenção de matéria-prima em restaurantes de culinária japonesa tem sido crescente. Por ser uma tipologia de empreendimento que já apresenta o maior ticket médio entre os estabelecimentos de alimentação (Minami, 2015) é necessário a busca de alternativas viáveis e bem aceitas pelos frequentadores destes estabelecimentos.

A Amazônia desponta como uma nova fonte de inspiração e ingredientes para chefs das mais variadas cozinhas. Ingredientes como tucupi, jambu, pimenta de cheiro, castanha do Pará e os peixes amazónicos tem estado presentes na ( $r$ )evolução culinária brasileira, liderada por chefs como Alex Atala, Claude Troigrois e Ana Trajano (Fajans, 2013).A autora descreve

The Amazon's famed biodiversity comes alive in the colorful sights and pungent scenes of the aisles and stalls of the plentiful Amazonian markets. The array of fruits and vegetables, plants and fish, nuts and berries, all sourced from the region astounds in the enormity of seasonal variability

Dentre os peixes da biodiversidade amazônica com maior potencial de aproveitamento em estabelecimentos de alimentação destacam-se o pirarucu, e o tambaqui, pois, correspondem aos peixes nativos com pacote tecnológico já em desenvolvimento para a aquicultura. A aquicultura é a fonte segura para abastecer com regularidade a demanda de pescados por restaurantes, já que,o estoque de pescados capturados (extrativismo) parece ter estagnado em 90 milhões de toneladas/ano, resultado da prática da sobrepesca predatória (Sidonio et al., 2012).
The Amazon's famed biodiversity comes alive in the colorful sights and pungent scenes of the aisles and stalls of the plentiful Amazonian markets. The array of fruits and vegetables, plants and fish, nuts and berries, all sourced from the region astounds in the enormity of seasonal variability

Among the fish species of the Amazon biodiversity with the greatest potential to be used in food establishments, pirarucu and tambaqui stand out since they are native fish species that already boast a technological package under development for aquaculture. Aquaculture is a safe source to regularly meet the demand for fish in restaurants since fish capture (extractivism) seems to have stagnated at 90 million tonnes/year, a result of overfishing (Sidonio et al., 2012).

Pirarucu (Arapaima gigas) is a large carnivore Amazonian fish and is considered the largest scale fish in the world. It is very important in the economy of Brazil's North region and is sold fresh or salted and dried (Nunes, Franco, Mársico \& Neves, 2012). With an excellent yield of meat for culinary use, its musculature is white, firm and mild flavored.

Tambaqui (Colossoma macropomum) is one of the most appreciated fish species in the region of the Amazon River and its tributaries. With brown and golden colors, it is an omnivore fish whose meat is tasty with an interesting texture and its broad, flexible spines are used to prepare the "rib" cut, which is widely consumed in the region. About this fish, Fernandes and Monteiro (2001) point out

Tambaqui's flavor is famous around the world and whoever gets to the Amazon and has already heard of it wastes no time in setting up a date for the pleasure of meeting it. After all, what's a fish with ribs like? Overall, it is prepared in as simple a way as possible, as the Amazonian Indians have taught [... And then, with the refinement of its pure flavor, it is prepared by those who know that in simplicity lies the zenith of sophistication. [...] The lauded ribs are wide, long spines that make us use the hands to enjoy them, as one does with ribs.

\section{METHODOLOGY}

A menu of cold and hot dishes was prepared using farmed native Amazonian fish prepared following Japanese cuisine techniques. For 
O pirarucu (Arapaima gigas) é um peixe amazônico carnívoro de grande porte, sendo considerado o maior peixe de escamas do mundo, de grande importância na economia da Região Norte, sendo vendido fresco ou na forma salgada e seca (Nunes, Franco, Mársico \& Neves, 2012). Com um excelente rendimento de carne para aproveitamento na culinária, apresenta musculatura branca, firme e de sabor suave.

O tambaqui (Colossoma macropomum) é um dos peixes mais apreciados na região do Rio Amazonas e seus afluentes. Com coloração parda e dourada, é um peixe onívoro, com uma carne saborosa, de textura interessante e espinhas largas e flexíveis, aproveitadas na preparação do corte "costela", bastante consumido na região. Sobre este peixe Fernandes \& Monteiro (2001) ressaltam

\begin{abstract}
O sabor do tambaqui é famoso mundo afora e quem chega à Amazônia e já ouviu falar dele não demora em marcar um encontro com o prazer de conhecêlo. Afinal, como será um peixe que tem costelas? Em geral é preparado da maneira mais simples possível, como os índios ensinaram [...] E assim, com o requinte da pureza de seu sabor, ele é preparado pelos que sabem ser na simplicidade o auge da sofisticação. [...] As decantadas costelinhas são espinhas largas e longas, que nos levam a usar as mãos para aproveitá-las, como costelinhas que são.
\end{abstract}

METODOLOGIA

Foi elaborado um cardápio de partos frios e quentes utilizando peixes nativos amazônicos cultivados preparados com técnicas da culinária japonesa, para esta etapa, foi constituído um corpo técnico formado por um chef de cozinha de uma rede de restaurantes japoneses do estado de São Paulo, chef de cozinha voltado à elaboração de pratos a partir de peixes nativos de água doce e pesquisadores da área de tecnologia e qualidade de alimentos.

$\mathrm{Na}$ oportunidade, foi utilizado o pirarucu (manta e lombo) e o tambaqui (costela). Dois pratos foram elaborados utilizando costelas de tambaqui: Fry de tambaqui (costelas de tambaqui marinadas, empanadas utilizando panko, fritas por imersão) e Tambaqui ao molho teriyaki (costelas marinadas no molho teriyaki e assadas em fogo baixo regadas com molho) (Figura 1). this step, a staff was gathered comprising a chef from a Japanese restaurant chain from the state of São Paulo, a chef specialized in preparing dishes based on native freshwater fish, and researchers in the area of food technology and quality.

At the occasion, pirarucu (dry-salted flanks and loin) and tambaqui (ribs) were used. Two dishes were prepared using tambaqui ribs: tambaqui fry (deep-fried marinated tambaqui ribs breaded with panko) and tambaqui teriyaki (ribs marinated in teriyaki sauce and roasted in low heat drizzled with sauce) (Figure 1).

For pirarucu, four dishes were prepared (Figure 2): marinated pirarucu (loin sliced following the sashimi technique briefly marinated in an acid solution); pirarucu tataki (sealed, marinated loin sliced following the sashimi technique and served with panko flakes); pirarucu teppan (seasoned flat fillets sautéed in a hot griddle and served with a side of fried shiitake and shimeji mushrooms or cooked vegetables); and pirarucu hot sushi (flank chips cut in strips rolled with cream cheese and Japanese rice, then breaded and fried). The dishes were selected and prepared according to the reported top-selling dishes at the restaurant chain.

A panel with 24 expert tasters was gathered, comprising food and nutrition professionals, aquaculture technicians, and Japanese restaurant owners. The same numbers of men and women were selected, the mean age was 21.3 years. In order to determine the profile of the panelists, they were requested to fill out a questionnaire inquiring about how often they consumed Japanese food.

The sensory acceptance of the dishes developed was assessed using a mixed ninepoint hedonic scale $(9=$ liked very much, 5 $=$ neither liked nor disliked, $1=$ disliked very much). The sensory attributes assessed were: appearance, aroma, flavor, and texture, as well as overall impression (Dutcosky, 2013).

Besides the hedonic scale, the consumers' intent to purchase the dishes based on their overall impression was assessed using a mixed five-point intent-to-purchase structured scale ( 5 = would certainly buy, 3 = maybe would buy, $1=$ would certainly not buy) for each of the dishes presented, which were priced at the same level as their current equivalents (salmon, tuna, and common snook) or 30 percent more expensive than their equivalents 
Para o pirarucu foram quatro preparações (Figura 2): Pirarucu marinado (lombo fatiado segundo a técnica de sashimi, marinado rapidamente em solução ácida); Tataki de pirarucu (lombo selado, marinado e fatiado conforme a técnica de sashimi, servido com flocos de panko); Teppan de pirarucu (Filés espalmados temperados salteados em chapa quente e servidos acompanhados de cogumelos shitake e shimeji fritos ou legumes cozidos) e Hot sushi de pirarucu (Aparas de manta cortadas em tiras e enroladas com cream cheese e arroz oriental, e então, empanadas e fritas). As preparações foram selecionadas e preparadas de acordo com os relatos da rede de restaurantes sobre seus pratos mais comercializados.

Formou-se um painel de 24 provadores especializados dentre profissionais da área da gastronomia e nutrição, técnicos em aqüicultura e proprietários de restaurantes japonesas. Foi selecionados a mesma quantidade de participantes homens e mulheres, com idade média de 21,3 anos, para a determinação do perfil dos painelistas que estavam realizando os testes, os mesmos foram solicitados a responderem um questionário informando a sua frequência de consumo em relação a comidas da cozinha japonesa.

A aceitação sensorial das preparações desenvolvidas foi avaliada por meio de Escala Hedônica estruturada mista de 9 pontos ( $9=$ gostei muitíssimo, 5=não gostei, nem desgostei, 1 =desgostei muitíssimo). Os atributos sensoriais avaliados foram: aparência, aroma, sabor, textura, bem como a impressão global (Dutcosky, 2013).

Além da escala hedônica, a intenção de compra dos consumidores em relação aos produtos, baseado na impressão geral destes sobre os mesmos, foi avaliada por meio da Escala de Intenção de Compra estruturada mista de 5 pontos $(5=$ certamente compraria, $3=$ tenho dúvidas se compraria, $1=$ certamente não compraria) para cada um dos pratos apresentados sendo eles na mesma faixa de preço de seus equivalentes atuais (Salmão, Atum e Camurim) ou $30 \%$ mais caros que seus similares (Stone \& Sidel, 2004). Os resultados do testes de Escala Hedônica e de Intenção de Compra foram listados no software PSPP 0.8.4 (Free Software Foundation Inc., Boston, MA, USA) onde foram feitas as tabelas descritivas de frequência.
(Stone \& Sidel, 2004). The hedonic scale and intent to purchase test results were listed in the software PSPP 0.8.4 (Free Software Foundation Inc., Boston, MA, USA), in which the frequency descriptive tables were made.

\section{RESULTS}

The acceptance of the dishes prepared with tambaqui ribs and pirarucu flank and loin is described in the tables below (Table 1 to 3 ).

When tasting the dishes presented, the panelists were asked about their intent to purchase and the dishes' attributes compared to similar ones prepared with common fish species in the market. That result is described in Table 4.

When the data in the table are analyzed, it must be pointed out that most tasters are regular consumers of Amazonian fish (at least once a week) and, to them, the flavor is the most important attribute when deciding on the purchase (68.0 percent). Since 64.0 percent of the tasters would buy the products presented even if the price were 30 percent higher compared to similar products, it can be said that the pilot test aiming to introduce Amazonian fish in the Japanese food niche market yielded positive results.

It is important to highlight that Japanese cuisine appreciates preserving the intrinsic properties of each component and valuing the seasonality of the local ingredients (Franco, 2001). Integrating Amazonian fish into this cuisine would not only favor valuing the ingredient by preserving its fresh characteristics that is so dear to this gastronomy, but also promote the local ingredient.

It can be seen that, during the early days of Japanese cuisine in Brazil, there was great zeal with tradition and preserving techniques and ingredients, however, the new generations of descendents became cultural agents crossing over "two worlds" with certain ease and opening the doors for integration as it has previously happened in North American and European countries (Ribeiro \& Paolucci, 2006).

Fischler (1990) also defends the positive result of using ingredients of a host country in foreign culinary techniques, emphasizing that fusion deeply influences local products, which take on a "least common denominator" derived from the characteristics of the original 


\section{RESULTADOS}

A aceitação dos pratos elaborados com a costela de tambaqui, lombo e manta de pirarucu encontra-se descritos nas tabelas abaixo (Tabelas 1 a 3 ).

Ao degustar os pratos apresentados, foi perguntado aos participantes da análise quanto à intenção de compra e seus atributos em relação a preparações similares executados com espécies de peixe comumente utilizadas no mercado. O resultado está descrito na Tabela 4.

Ao analisar os dados da tabela, é importante ressaltar que a maioria dos provadores são consumidores regulares de peixes amazônicos (pelo menos uma vez por semana) e para estes o sabor é o atributo de maior importância na decisão de compra $(68,0 \%)$. Considerando que $64,0 \%$ dos provadores comprariam os produtos apresentados, mesmo que houvesse aumento de até $30 \%$ dos preços em relação a produtos similares, pode-se afirmar que o teste piloto visando à inserção de pescado amazônico no nicho de mercado da culinária oriental foi positivo.

É importante destacar que a culinária japonesa preza pela preservação das propriedades intrínsecas de cada componente e valorização da sazonalidade dos ingredientes locais (Franco, 2001). A integração de peixes amazônicos a esta culinária, não apenas favoreceria a valorização do ingrediente, preservando suas características de fresco, tão valorizada nesta cozinha, além da promoção do ingrediente local.

Percebe-se que no advento da cozinha japonesa no Brasil, havia um zelo pela tradição e preservação de técnicas e ingredientes, no entanto, após a constituição de novas gerações de descendentes nipônicos, tornaram-se agentes culturais transitando entre "dois mundos" com certa facilidade e abrindo portas para integração como já ocorrera previamente em países da América do Norte e Europa (Ribeiro \& Paolucci, 2006).

Fischler (1990) também defende o resultado positivo do uso de ingredientes de um país receptor por técnicas culinárias estrangeiras, enfatizando que a fusão influencia de sobremaneira produtos locais e seus sabores, que passam a receber um "minímo denominador comum" decorrente das características da cozinha genuína, adaptando estes produtos locais ao consumidor global.

Quando comparados os pratos entre si, é possível observar que as preparações de cuisine by adapting the local products to the global consumer.

When the dishes are compared, one can see that the teppan ones were the most appreciated, in contrast with pirarucu hot sushi, which obtained the lowest acceptance index, though still with a sizeable margin for it to pose an alternative in the menu using Amazonian fish.

As for the tendency to continue consuming the dishes and recommend them to friends, 16.0 percent of the tasters would always recommend them while 44.0 percent would often recommend the consumption of products prepared with Amazonian fish. Pirarucu teppan also obtained the highest averages in the individual evaluation of this item as 40.0 percent of the tasters would always recommend its consumption, which makes the dishes relevant to be inserted into local food establishments and even in other regions. That would value Amazonian fish and offer new market niches, particularly to family fishermen and fish farmers, since this dietary trend may be offered bound to the identity constraints of the Amazonian productive/ extractivist culture and its members (Poulain \& Proença, 2003).

\section{FINAL CONSIDERATIONS}

New cuisine hybridizations have spawned with the information exchange and interculturality, which leads to new identities and forms of consumption. In this sense, preparing Amazonian fish employing the techniques of Japanese cuisine not only strengthens the well-known versatility of the ingredients of the Amazon, but also paves the way for a gastronomic product with a strong touristic appeal while offering sustainable alternatives that promote the development of local production schemes to rooted Japanese restaurants that may find in Amazonian fish a source of inspiration, flavors, and innovation in their menus.

\section{REFERENCES}

Barroco, L. M. S. \& Barroco, H. E. (2008). A importância da gastronomia como patrimônio cultural, no turismo baiano. 
Teppan foram as inclusões mais apreciadas, em oposição ao Hot sushi de pirarucu que obteve o menor índice de aceitação, mas ainda com uma margem interessante para configurar uma alternativa de cardápio a partir de peixes amazônicos.

Quanto à tendência em continuar consumindo e indicar aos amigos $16,0 \%$ dos provadores indicariam sempre, e $44,0 \%$ indicariam frequentemente 0 consumo dos produtos elaborados com peixes amazônicos, sendo que o Teppan de pirarucu também obteve as maiores médias na avaliação individual deste item com 40,0\% dos provadores indicando sempre seu consumo, - que torna as preparações interessantes para a inserção em empreendimentos locais e mesmo fora da região, valorizando assim, os peixes amazônicos e oferecendo novos nichos de mercado, principalmente a pescadores e piscicultores familiares, já que esta tendência alimentar pode ser oferecida ligada as fronteiras de identidade de uma cultura produtiva/extrativista amazônida e os membros que a constituem (Poulain \& Proença, 2003).

\section{CONSIDERAÇÕES FINAIS}

Novas hibridizações da culinária vêm sendo criadas com o intercâmbio de informações e a interculturalidade, gerando novas identidades e formas de consumo. Nesse sentido, o preparo de peixes amazônicos utilizando técnicas da culinária japonesa, não apenas reforça a já bem conhecida versatilidade dos ingredientes do bioma Amazônia, como gera uma nova faceta de produto gastronômico com forte apelo turístico e oferece alternativas sustentáveis e que promovem o desenvolvimento de arranjos produtivos locais para restaurantes japoneses já bem estabelecidos que poderão ter nos pescados amazônicos mais uma fonte de inspiração, sabores e inovação para seus cardápios.

\section{REFERÊNCIAS}

Barroco, L. M. S. \& Barroco, H. E. (2008). A importância da gastronomia como patrimônio cultural, no turismo baiano. TURYDES, 1(2).

Boletim Estatístico da pesca e aquicultura. (2011). Ministério da Pesca e Aqüicultura. Brasília: MPA.

Brayner, N. G. (2007). Patrimônio Cultural
TURYDES, 1(2).

Boletim Estatístico da pesca e aquicultura. (2011). Ministério da Pesca e Aqüicultura. Brasília: MPA.

Brayner, N. G. (2007). Patrimônio Cultural Imaterial: para saber mais. Brasília: IPHAN.

Carneiro, H. (2003). Comida e sociedade: uma história da alimentação. Rio de Janeiro: Campus.

Collaço, J. H. L. (2009). Sabores e memórias: cozinha italiana e construção identitária em São Paulo. Tese de doutorado. Faculdade de Filosofia, Letras e Ciências Humanas, Universidade de São Paulo, São Paulo, Brasil.

Cunha, K. B. \& Oliveira, L. V. (2009) A gastronomia enquanto atrativo turístico cultural. 2009. Dissertação de Mestrado. Universidade Estadual de Goiás, Goiás, Brasil.

Cwiertka, K. J. (2005). From Ethnic to Hip: Circuits of Japanese Cuisine in Europe. Food and Foodways, 13(4), 241-272. doi: 10.1080/07409710590931294

Dutcosky, S.D. (2013). Análise sensorial de alimentos. Curitiba: Champagnat. 531p.

Fajans, J. (2013). Brazilian Food: Race, Class and Identity in Regional Cuisines. Londres: A\&C Black, 160p.

Fernandes, C. \& Monteiro, S. (2001). Viagem gastronômica através do Brasil. São Paulo: Senac.

Figueiredo, F. B. (2009). Patrimônio Imaterial e Turismo: a cultura gastronômica do agnolini. 2009. Dissertação (Mestrado em Turismo) Universidade de Caxias do Sul, Rio Grande do Sul.

Fischler C. (1990). L'Homnivore. Paris: Odile Jacob.

Franco, A. (2001). De caçador a gourmet: uma história da gastronomia. 2 ed. rev. São Paulo: Senac.

Holzmann, S. N. (2006). Sushi: sabor milenar. 1. ed., São Paulo: Publifolha. 181p.

Laemmerhirt, I. A. (2010). Imagining the Taste: Transnational Food Exchanges between Japan and the United States. The Japanese Journal of American Studies, 21. Retrieved from http://www. americanspace-leipzig.de/wp-content/ uploads/2015/06/Iris-Laemmerhirt. Transnational-Food-Exchanges.pdf

Martins, J. S. (1997). Fronteira: a degradação do outro nos confins do humano. São Paulo: Hucitec.

Medina, I. (2006). As cozinhas do Japão. São Paulo: Moderna.

Minami, T. (2015, 29 de março). Os anos 90 também estão de volta na gastronomia. Revista CQ. Retrieved 
Imaterial: para saber mais. Brasília: IPHAN.

Carneiro, H. Comida e sociedade: uma história da alimentação. Rio de Janeiro: Campus, 2003.

Collaço, J. H. L. (2009). Sabores e memórias: cozinha italiana e construção identitária em São Paulo. Tese de doutorado. Faculdade de Filosofia, Letras e Ciências Humanas, Universidade de São Paulo, São Paulo, Brasil.

Cunha, K. B. \& Oliveira, L. V. (2009) A gastronomia enquanto atrativo turístico cultural. 2009. Dissertação de Mestrado. Universidade Estadual de Goiás, Goiás, Brasil.

Cwiertka, K. J. (2005). From Ethnic to Hip: Circuits of Japanese Cuisine in Europe. Food and Foodways, 13(4), 241-272. doi: 10.1080/07409710590931294

Dutcosky, S.D. (2013). Análise sensorial de alimentos. Curitiba: Champagnat. 531p.

Fajans, J. (2013). Brazilian Food: Race, Class and Identity in Regional Cuisines. Londres: A\&C Black, 160p.

Fernandes, C. \& Monteiro, S. (2001). Viagem gastronômica através do Brasil. São Paulo: Senac.

Figueiredo, F. B. Patrimônio Imaterial e Turismo: a cultura gastronômica do agnolini. 2009. Dissertação (Mestrado em Turismo) Universidade de Caxias do Sul, Rio Grande do Sul, 2009.

Fischler C. (1990). L'Homnivore. Paris: Odile Jacob.

Franco, A. (2001). De caçador a gourmet: uma história da gastronomia. 2 ed. rev. São Paulo: Senac.

Holzmann, S. N. (2006). Sushi: sabor milenar. 1. ed., São Paulo: Publifolha. 181p.

Laemmerhirt, I. A. (2010). Imagining the Taste: Transnational Food Exchanges between Japan and the United States. The Japanese Journal of American Studies, 21. Recuperado de http://www. americanspace-leipzig.de/wp-content/ uploads/2015/06/Iris-Laemmerhirt. Transnational-Food-Exchanges.pdf

Martins, J. S. (1997). Fronteira: a degradação do outro nos confins do humano. São Paulo: Hucitec.

Medina, I. (2006). As cozinhas do Japão. São Paulo: Moderna.

Minami, T. (2015, 29 de março). Os anos 90 também estão de volta na gastronomia. Revista CQ. Recuperado de http:// gq.globo.com/Prazeres/Gastronomia/ noticia/2015/03/os-anos-90-tambemestao-de-volta-na-gastronomia.html

Nunes, E.S.C.L., Franco, R. M., Mársico, E. T. \& Neves, M. S. from http://gq.globo.com/Prazeres/Gastronomia/ noticia/2015/03/os-anos-90-tambem-estao-devolta-na-gastronomia.html

Nunes, E.S.C.L., Franco, R. M., Mársico, E. T. \& Neves, M. S. (2012). Qualidade do pirarucu (Arapaima gigas Shing, 1822) salgado seco comercializado em mercados varejistas. Revista do Instituto Adolfo Lutz,71(3) , 520-529. Retrieved from http://periodicos.ses. sp.bvs.br/scielo.php?script=sci_arttext \&pid=S007398552012000300013\&lng=pt\&tlng=pt

Oda, E. (2011). Interpretações da "cultura japonesa" e seus reflexos no Brasil. Revista Brasileira de Ciências Sociais, 75(26). doi: 10.1590/S0102-69092011000100006

Poulain, J.P. \& Proença, R.P.C. (2003). O espaço social alimentar: um instrumento para o estudo dos modelos alimentares". Revista de Nutrição, vol. 16, n. 3, p 145156, 2003

Reichembarch, M. T. (2007). História e alimentação: o advento do fast food e as mudanças dos hábitos alimentares em Curitiba (1960-2002). Tese de doutorado. Universidade Federal do Paraná, Curitiba, Paraná, Brasil.

Ribeiro, C. M. A \& Paolucci, L. (Julho, 2006). Gastronomia, Interação cultural e Turismo: estudo sobre a dispersão da culinária nipônica na Cidade de São Paulo - 100 anos da imigração japonesa no Brasil. Anais do Seminário de Pesquisa em Turismo do Mercosul, Caixas do Sul, Rio Grande so Sul, Brasil 4.

Ribeiro, C. M. A. (2005). A questão da mídia na difusão da gastronomia japonesa no Brasil.Relações Interétnicas - Fricção e Interação. São Paulo: Belas Artes.

Sampaio, F. (2010). A gastronomia como produto turístico. Exedra: Revista Científica, 4. Retrieved from www. exedrajournal.com/docs/S-tur/06sampaio-134.pdf

Schlüter, R. G. (2003). Gastronomia e turismo. São Paulo: Aleph.

Sidonio, L., Cavalcanti, I., Capanema, L.., Morch, R., Lima, L., Burns, V., Alves Júnior, A. J., Amaral, J. V. (2012). Experiências internacionais aquícolas e oportunidades de desenvolvimento da aquicultura no Brasil: proposta de inserção do BNDES. BNDES Setorial, 1(36), 179-218. Retrieved from http://www.bndes.gov.br/SiteBNDES/ export/sites/default/bndes_pt/Galerias/ Arquivos/conhecimento/bnset/set3605. pdf

Silva, A. B.; Soares, A. L. R. \& Wolf, R. A. (2011). Registro da gastronomia japonesa como patrimônio imaterial dos nikkeis residentes no Brasil. Mouseion, 10, 150157. Retrieved from http://www.revistas. 
(2012). Qualidade do pirarucu (Arapaima gigas Shing, 1822) salgado seco comercializado em mercados varejistas. Revista do Instituto Adolfo Lutz,71(3) , 520-529. Recuperado de http://periodicos.ses. sp.bvs.br/scielo.php?script=sci_arttext \&pid=S007398552012000300013\&lng=pt\&tlng=pt

Oda, E. (2011). Interpretações da "cultura japonesa" e seus reflexos no Brasil. Revista Brasileira de Ciências Sociais, 75(26). doi: 10.1590/S0102-69092011000100006

Poulain, J.P. \& Proença, R.P.C. (2003). O espaço social alimentar: um instrumento para o estudo dos modelos alimentares". Revista de Nutrição, vol. 16, n. 3, p 145156,2003

Reichembarch, M. T. (2007). História e alimentação: o advento do fast food e as mudanças dos hábitos alimentares em Curitiba (1960-2002). Tese de doutorado. Universidade Federal do Paraná, Curitiba, Paraná, Brasil.

Ribeiro, C. M. A. (2005). A questão da mídia na difusão da gastronomia japonesa no Brasil.Relações Interétnicas - Fricção e Interação. São Paulo: Belas Artes.

Ribeiro, C. M. A \& Paolucci, L. (Julho, 2006). Gastronomia, Interação cultural e Turismo: estudo sobre a dispersão da culinária nipônica na Cidade de São Paulo - 100 anos da imigração japonesa no Brasil. Anais do Seminário de Pesquisa em Turismo do Mercosul, Caixas do Sul, Rio Grande so Sul, Brasil 4.

Sampaio, F. (2010). A gastronomia como produto turístico. Exedra: Revista Científica, 4. Recuperado de www. exedrajournal.com/docs/S-tur/06sampaio-134.pdf

Sidonio, L., Cavalcanti, I., Capanema, L.., Morch, R., Lima, L., Burns, V., Alves Júnior, A. J., Amaral, J. V. (2012). Experiências internacionais aquícolas e oportunidades de desenvolvimento da aquicultura no Brasil: proposta de inserção do BNDES. BNDES Setorial, 1(36), 179-218. Recuperado de http://www.bndes.gov.br/SiteBNDES/ export/sites/default/bndes_pt/Galerias/ Arquivos/conhecimento/bnset/set3605. pdf

Schlüter, R. G. (2003). Gastronomia e turismo. São Paulo: Aleph.

Silva, A. B.; Soares, A. L. R. \& Wolf, R. A. (2011). Registro da gastronomia japonesa como patrimônio imaterial dos nikkeis residentes no Brasil. Mouseion, 10, 150157. Recuperado de http://www.revistas.unilasalle. edu.br/index.php/Mouseion/article/view/247/248

Sonati, J. G., Vilarta, R. \& Silva, C. C. (2009). Influências Culinárias e Diversidade Cultural da Identidade Brasileira: Imigração, Regionalização e suas Comidas. In R. T.
unilasalle.edu.br/index.php/Mouseion/ article/view/247/248

Sonati, J. G., Vilarta, R. \& Silva, C. C. (2009). Influências Culinárias e Diversidade Cultural da Identidade Brasileira: Imigração, Regionalização e suas Comidas. In R. T. Mendes, R. Vilarta \& G. L. Gutierrez (Orgs.). Qualidade de Vida e Cultura Alimentar. Curitiba: IPES Editora.

Stone, H., Sidel, J. L. (2004). Sensory evaluation practices. 3ed. New York: Academic, $338 \mathrm{p}$.

Torre, J. (Janeiro, 2014). Balança comercial: o déficit aumenta. Seafood Brasil, 4, 30-34. Retrieved from http://issuu.com/seafoodbrasil/docs/seafood_ brasil 4

Zaneti, T. B. (2012). Das panelas das nossas avós aos restaurantes de alta gastronomia: os processos sociais de valorização de produtos agroalimentares tradicionais. Dissertação de mestrado. Faculdade de Agronomia e Medicina Veterinária, Universidade de Brasília, Brasília, Distrito Federal, Brasil. 
Mendes, R. Vilarta \& G. L. Gutierrez (Orgs.). Qualidade de Vida e Cultura Alimentar. Curitiba: IPES Editora.

Stone, H., Sidel, J. L. (2004). Sensory evaluation practices. 3ed. New York: Academic, $338 \mathrm{p}$.

Torre, J. (Janeiro, 2014). Balança comercial: o déficit aumenta. Seafood Brasil, 4, 30-34. Recuperado de http://issuu.com/seafoodbrasil/docs/seafood_ brasil_4 4

Zaneti, T. B. (2012). Das panelas das nossas avós aos restaurantes de alta gastronomia: os processos sociais de valorização de produtos agroalimentares tradicionais. Dissertação de mestrado. Faculdade de Agronomia e Medicina Veterinária, Universidade de Brasília, Brasília, Distrito Federal, Brasil. 

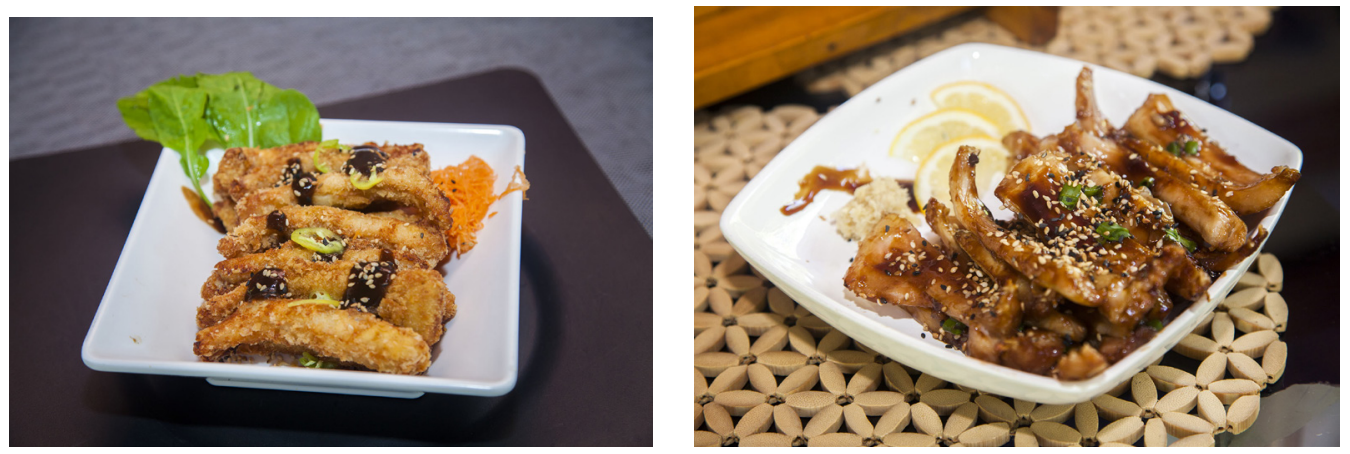

Figura 1. Preparações elaboradas a partir das costelas de tambaqui. (A) Fry de tambaqui e (B) Tambaqui ao molho teriyaki. Fotos: Jefferson Christofoletti

Figure 1. Dishes prepared with tambaqui ribs. (A) Tambaqui fry and (B) tambaqui teriyaki. Source: Jefferson Christofoletti (2015)
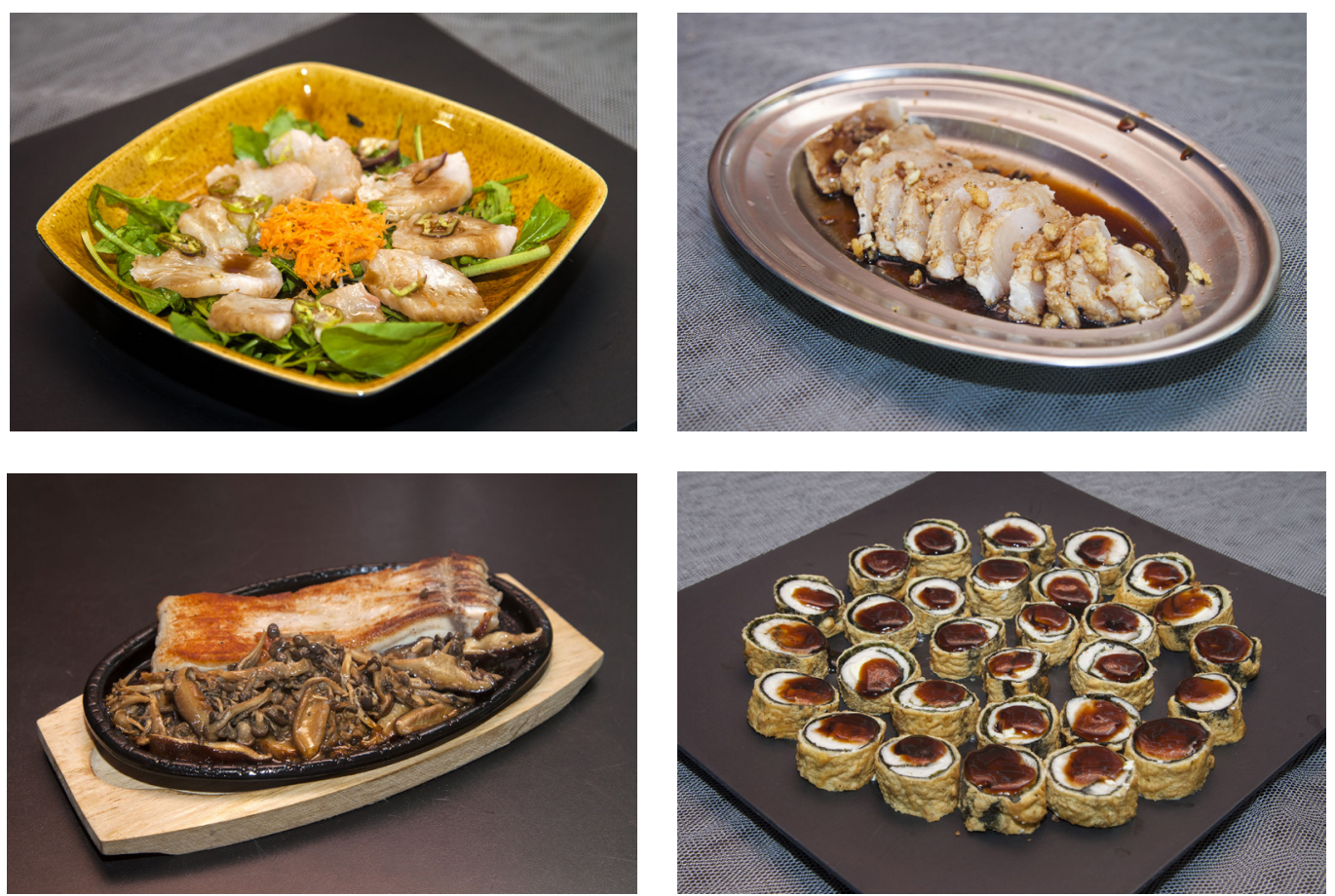

Figura 2. Preparações elaboradas a partir do lombo e manta de pirarucu. Pratos elaborados com o lombo: (A) Lombo marinado e (B) Tataki de pirarucu. Pratos elaborados com a manta: (C) Teppan de pirarucu e (D) Hot sushi de pirarucu. Fotos: Jefferson Christofoletti

Figure 2. Recipes prepared with pirarucu flank and loin. Dishes prepared with the loin: (A) Marinated loin and (B) pirarucu tataki. Dishes prepared with the flank: (C) Pirarucu teppan and (D) pirarucu hot sushi. Source: Jefferson Christofoletti (2015) 
Tabela 1 - Médias de aceitação de consumidores em relação ao sabor, textura, aparência e aceitação global das amostras de pratos elaborados usando costelinhas de Tambaqui

\begin{tabular}{lcc}
\hline Atributos & Fry de tambaqui & Tambaqui ao molho teriyaki \\
\hline Aparência & $8,69 \pm 0,60$ & $8,31 \pm 0,87$ \\
Textura & $8,38 \pm 0,81$ & $8,50 \pm 0,63$ \\
Sabor & $8,31 \pm 0,79$ & $8,19 \pm 0,91$ \\
Aceitação global & $8,38 \pm 0,81$ & $8,56 \pm 0,81$ \\
\hline
\end{tabular}

Fonte: autores, 2014

Table 1 - Average acceptance by consumers regarding flavor, texture, appearance, and overall acceptance of the samples of dishes prepared using tambaqui ribs

\begin{tabular}{|l|c|c|}
\hline Attributes & Tambaqui fry & Tambaqui teriyaki \\
\hline Appearance & $8.69 \pm 0.60$ & $8.31 \pm 0.87$ \\
\hline Texture & $8.38 \pm 0.81$ & $8.50 \pm 0.63$ \\
\hline Flavor & $8.31 \pm 0.79$ & $8.19 \pm 0.91$ \\
\hline Global acceptance & $8.38 \pm 0.81$ & $8.56 \pm 0.81$ \\
\hline
\end{tabular}

Source: Authors, 2014.

Tabela 2 - Médias de aceitação de consumidores em relação ao sabor, textura, aparência e aceitação global das amostras de pratos elaborados usando o lombo de Pirarucu

\begin{tabular}{lcc}
\hline Atributos & Marinado de pirarucu & Tataki de pirarucu \\
\hline Aparência & $8,25 \pm 0,68$ & $8,12 \pm 1,17$ \\
Textura & $8,63 \pm 0,50$ & $8,24 \pm 1,25$ \\
Sabor & $8,63 \pm 0,72$ & $7,94 \pm 1,44$ \\
Aceitação global & $8,25 \pm 0,45$ & $8,41 \pm 1,00$ \\
\hline
\end{tabular}

Fonte: autores, 2014

Table 2 - Average acceptance by consumers regarding flavor, texture, appearance, and overall acceptance of the samples of dishes prepared using pirarucu loin

\begin{tabular}{|l|c|c|}
\hline Attributes & Pirarucu marinate & Pirarucu tataki \\
\hline Appearance & $8.25 \pm 0.68$ & $8.12 \pm 1.17$ \\
\hline Texture & $8.63 \pm 0.50$ & $8.24 \pm 1.25$ \\
\hline Flavor & $8.63 \pm 0.72$ & $7.94 \pm 1.44$ \\
\hline Overall acceptance & $8.25 \pm 0.45$ & $8.41 \pm 1.00$ \\
\hline
\end{tabular}

Source: Authors, 2014. 
Tabela 3 - Médias de aceitação de consumidores em relação ao sabor, textura, aparência e aceitação global das amostras de pratos elaborados usando a manta de Pirarucu

\begin{tabular}{lcc}
\hline Atributos & Teppan de pirarucu & Hot sushi de pirarucu \\
\hline Aparência & $8,88 \pm 0,34$ & $8,38 \pm 0,96$ \\
Textura & $8,88 \pm 0,34$ & $6,81 \pm 1,38$ \\
Sabor & $8,88 \pm 0,34$ & $7,13 \pm 2,22$ \\
Aceitação global & $8,63 \pm 0,72$ & $7,25 \pm 0,93$ \\
\hline
\end{tabular}

Fonte: autores, 2014

Table 3 - Average acceptance by consumers regarding flavor, texture, appearance, and overall acceptance of the samples of dishes prepared using pirarucu flank

\begin{tabular}{|l|c|c|}
\hline Attributes & Pirarucu teppan & Pirarucu hot sushi \\
\hline Appearance & $8.88 \pm 0.34$ & $8.38 \pm 0.96$ \\
\hline Texture & $8.88 \pm 0.34$ & $6.81 \pm 1.38$ \\
\hline Flavor & $8.88 \pm 0.34$ & $7.13 \pm 2.22$ \\
\hline Overall acceptance & $8.63 \pm 0.72$ & $7.25 \pm 0.93$ \\
\hline
\end{tabular}

Source: Authors, 2014.

Tabela 4 - Intenção de compra relativa aos pratos apresentados em relação aos produtos já encontrados no mercado da culinária japonesa, em porcentagem

\begin{tabular}{|c|c|c|c|c|c|}
\hline \multirow[b]{2}{*}{ Questionamento } & \multicolumn{5}{|c|}{ Intenção de compra } \\
\hline & Certamente sim & Provavelmente sim & Talvez & $\begin{array}{l}\text { Certamente } \\
\text { não }\end{array}$ & $\begin{array}{c}\text { Provavelmente } \\
\text { não }\end{array}$ \\
\hline $\begin{array}{l}\text { Você compraria esse } \\
\text { produto? }\end{array}$ & 64,0 & 26,0 & - & - & - \\
\hline $\begin{array}{l}\text { Você compraria esse } \\
\text { produto caso ele fosse } 30 \% \\
\text { mais caro que seu similar? }\end{array}$ & 64,0 & 13,0 & 13,0 & - & - \\
\hline
\end{tabular}

Fonte: autores, 2014

Table 4 - Intent to purchase the dishes presented compared to the products already in the Japanese food market, as percentages

\begin{tabular}{|l|c|c|c|c|c|}
\hline & \multicolumn{5}{|c|}{ Intent to purchase } \\
\hline $\begin{array}{l}\text { Inquiry } \\
\begin{array}{l}\text { Would you buy this } \\
\text { product? }\end{array}\end{array}$ & Certainly yes & Likely yes & Maybe & Certainly not & Likely not \\
\hline $\begin{array}{l}\text { Would you buy this product } \\
\text { if it cost 30 percent more } \\
\text { than a similar one? }\end{array}$ & 64.0 & 26.0 & - & - & - \\
\hline
\end{tabular}

Source: Authors, 2014.

114 - Applied Tourism Kato et al. 